\title{
The status of the Hoopoe (Upupa epops) in Hungary: a review
}

\author{
Gergő Halmos ${ }^{1 *}$, Károly Nagy ${ }^{1}$, Zsolt Karcza ${ }^{1} \&$ Tibor Szép ${ }^{2}$
}

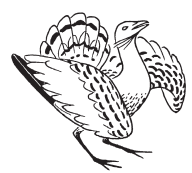

Gergő Halmos, Károly Nagy, Zsolt Karcza \& Tibor Szép 2015. The status of the Hoopoe (Upupa epops) in Hungary: a review. - Ornis Hungarica 23(2): 1-9. sibility to summarise the information about the distribution, population size, dispersion, migration as well as the nature conservation status of the Hoopoe population breeding in Hungary. In the period of 1999-2014 the number of breeding pairs and trend of population level was estimated based on the Common Bird Census database. The population size was estimated as $13,500-17,500$ pairs with a stable trend (slope $=-1.3 \%$, SE $=2.5 \%$ ) over 19992014. There is very limited information on migration from bird ringing, only 8 recoveries between 1928-1963 indicate, that the Hungarian population is migrating on a south-southeast direction in autumn, wintering in the eastern parts of the Sahel, possibly in Chad and Sudan and migrates back in spring following a loop migration pattern further to the east. The main conservation issues are agricultural intensification impacting feeding possibilities, lack of nesting cavities and hunting during migration.

Keywords: Upupa epops, Hungary, breeding population, migration, conservation

Összefoglalás A búbosbanka általánosan elterjedt faj Magyarországon. Legjelentősebb állományai az Alföldön találhatóak. Az a tény, hogy a faj 2015-ben az „Év Madara” lett, lehetőséget ad, hogy összegezzük ismereteinket a faj magyarországi elterjedéséről, állományáról, diszperziójáról, vonulásáról és védelmi helyzetéről. A költőállományt és annak változását a Mindennapi Madaraink Monitoringja (MMM) program 1999-2014 évi adatai alapján becsültük. A hazai állománynagyságra adott becslés $13500-17500$ pár, és trendje stabil (meredekség=-1,3\%, $\mathrm{SE}=2,5 \%$ ). A faj vonulásáról nagyon keveset tudunk a madárgyürüzési adatok alapján. Csak 8 megkerülési adat származik az 1928-1963 közötti időszakból, amelyek azt mutatják, hogy az őszi vonulási irány dél-délnyugati, a telelési terület a Száhel-övezet keleti részében, Csád és Szudán területén valószínüsíthető, és tavasszal a máshol is megfigyelt hurokvonulási mintázat alapján a madarak keletebbre vonulhatnak. A fö természetvédelmi tényezők a mezögazdaság intenzifikálódása - amely a táplálkozási lehetőségekre gyakorol hatást -, a költő̈rregek hiánya, és a vonulási útvonalon tapasztalható vadászati nyomás.

Kulcsszavak: Upupa epops, Magyarország, költőpopuláció, vonulás, természetvédelem

${ }^{1}$ MME/BirdLife Hungary, 1121 Budapest, Költö utca 21., Hungary, e-mail: halmos.gergo@mme.hu ${ }^{2}$ Institute of Environmental Sciences, University of Nyíregyháza, 4400 Nyíregyháza, Sóstói út 31/b, Hungary

*corresponding author

\section{Introduction}

The Hoopoe (Upupa epops) is a polytypic species. The nominate form occurs in Northwest Africa, Europe, north to the $60^{\circ} \mathrm{N}$ latitude, east to Siberia and East China. There are 8 subspecies in sub-Saharan Africa,
Madagascar and Asia. The nominate from is mostly migratory.

This species occupies open country such as pastures, parkland, orchards, sand-heathland, olive groves, and vineyards and requires the presence of features offering perches, shade, nest-sites and accessible 
food. It is frequently found around villages and in traditionally farmed areas. Breeding can occur up to $3000 \mathrm{~m}$ in Turkey (Krištín \& Kirwan 2014). In Central and Southern Europe, egg-laying occurs from late April or early May, although begins in January in the Canaries (Snow \& Perrins 1998). The species is monogamous, solitary and a territorial breeder, although extra-pair paternity has been found in Southeast Spain (Martín-Vivaldi et al. 2002). It nests in natural holes in stumps, trees, walls, old buildings, cliffs, among boulders, in abandoned vehicles, drainpipes, wells, roof spaces and nest boxes and may use the same site for several seasons (Krištín \& Kirwan 2014). It feeds almost entirely on animal matter, primarily large insects and their larvae and pupae (Snow \& Perrins 1998). Northern populations are fully migratory while others are only partially migratory. European populations winter in northwest Africa, the Canary Isles, Israel and Arabia (Krištín \& Kirwan 2014).

In 2015 the Hoopoe became the 'Bird of The Year' in Hungary (Bank 2015), which makes it very timely to summarize our knowledge about the status of the species in the country and to emphasize the future research and conservation priorities.

\section{Geographical distribution}

The species has an extremely large range covering more than 28 million $\mathrm{km}^{2}$ (BirdLife International 2015a). The nominate breeds from Northwest Africa (east to Libya), Canary Island, Central and Southern Europe south to Lebanon, Jordan and Israel (as far South as North Negev), and east to South-Central Russia (Ob-Yenisey watershed), Northwest China (Xinjiang) and Northwest India; probably this race breeding in North, Central and East Arabia (Krištín \& Kirwan 2014).

In Hungary the species was known to be widespread with stronger populations on the Great Plains and other open areas with sandy soil types (Bankovics 1984, Magyar et al. 1998, Hadarics \& Zalai 2008). There were no distribution maps published. Based on data from several general monitoring schemes we collected all available information to provide a first distribution map for the species. The dataset included the Common Bird Census (MMM - Mindennapi Madaraink Monitoringja), and the first year of the Breeding Bird Atlas project. We provide the dataset in a $10 \times 10 \mathrm{~km}$ UTM grid map, showing surveyed grids with and without confirmed breeding (Figure 1). Some areas still exist in Hungary, where we have very little information, but the general picture shows well, that the species is still widespread, prefers the open lowland areas and avoids the areas with a high forest coverage.

\section{Breeding population}

The global population of the species is very large, estimated to be over 5 million mature individuals (Birdlife International 2015a). The European breeding population was assessed in 2004 to be large ( $>890,000$ pairs) and was stable between 1970-2000, although several populations underwent moderate declines $(>10 \%)$ (BirdLife International 2004). In 2014 the European population was estimated at 1,300,000-2,760,000 pairs, which equates to $2,600,000-5,530,000$ mature individuals. The population in the EU27 was estimated at 1,020,000-2,070,000 pairs, which equates to $2,040,000-4,140,000$ mature in- 


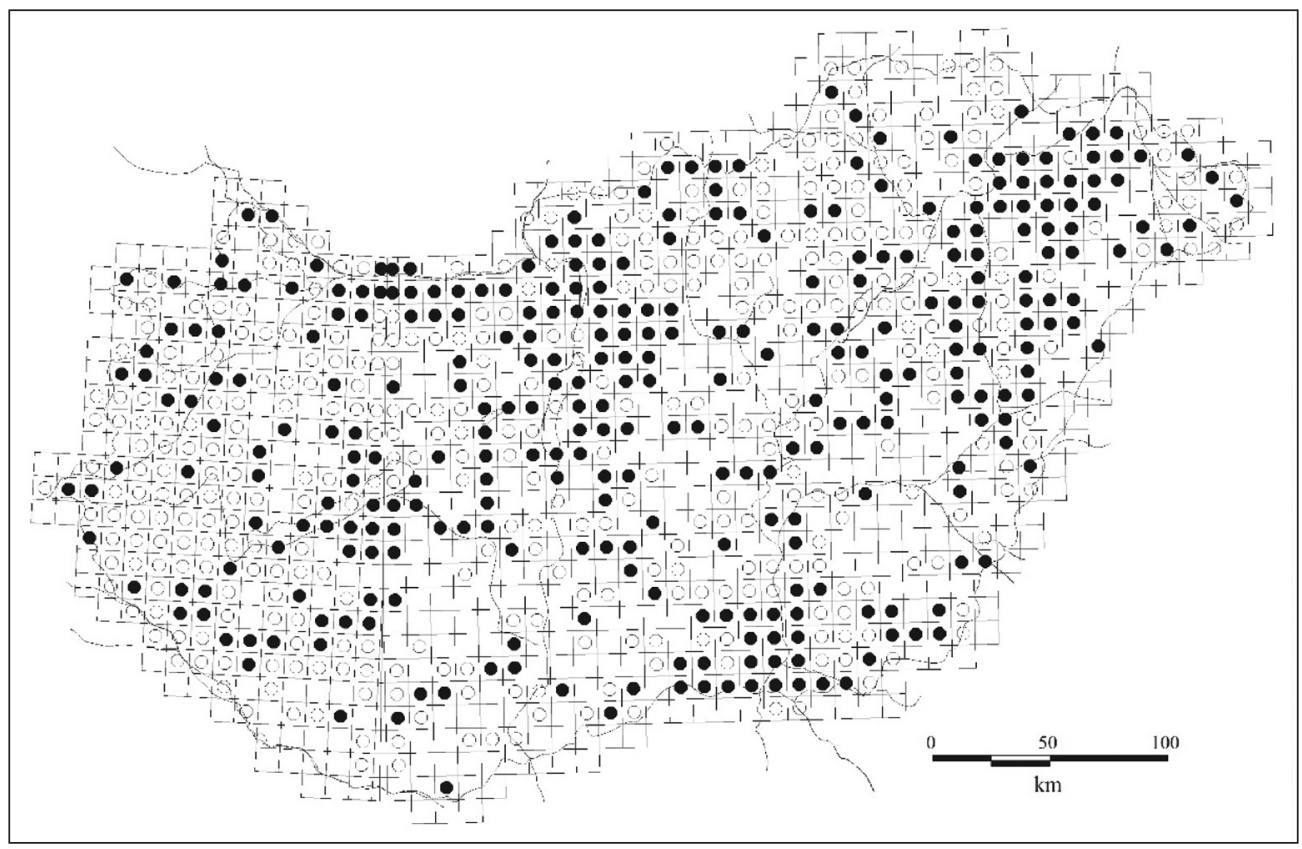

Figure 1. Distribution of $10 \times 10 \mathrm{~km}^{2}$ UTM squares in Hungary where breeding pairs of Hoopoes were observed during 1999-2014. Every square surveyed is marked with a circle, which is an open circle if there is no confirmed breeding for the Hoopoe, and a filled circle if there is confirmed breeding

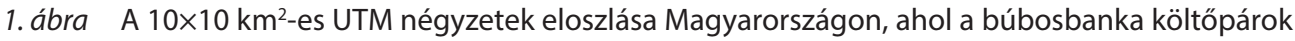
megfigyelése történt 1999-2014 között

dividuals. In Europe the strongest populations are on the Iberian Peninsula with $815,000-1,710,000$ pairs giving $62 \%$ of the European estimated population size. There are other significant populations in France, Italy, Greece and Turkey (BirdLife International 2015a, 2015b).

Specific surveys were not done for the species in Hungary, but the population was estimated in several general studies and publications. Generally the species is treated as fairly common, especially on the Great Plains with higher densities on sandy soil areas (Bankovics 1984). The species was described as widespread and fairly numerous by Nándor Homonnay in 1938 and he estimated to have at least a few hundred pairs nesting in the region of Lake Balaton (Homonnay 1938).
The population was estimated to be between 8000-10,000 pairs in 1998 and being a fairly common breeder especially on the Great Plain (Magyar et al. 1998). The next edition of this publication estimated the breeding population min. 10,000, max. 17,000 pairs between 1990-2002. The population density was higher in the Great Plain than Transdanubia and in the northern part the country (Hadarics \& Zalai 2008). This estimation was used in international assessments as well (BirdLife International 2004).

The global population is declining on the long term throughout its range due to habitat loss and over-hunting (Krištín \& Kirwan 2014). The trend of the European population was recently assessed in details in the European Red List of birds project (BirdLife 
International 2015b) and the population size is estimated to be stable in Europe and in the EU27 countries as well. A detailed study of the Swiss population - where Hoopoe is a rare bird - has shown, that it has increased between $2002-2010$ by $11 \%$. Hoopoe population growth rate was strongly correlated with juvenile survival, fecundity and immigration, which indicates that demographic components impacting the arrival of new individuals into the populations were more important for their dynamics than demographic components affecting the loss of individuals (Schaub et al. 2012).

In 2013-2014 MME/BirdLife Hungary prepared new assessments for the species for the Ministry of Agriculture to be used in the formal EU Birds Directive reporting process. As there were no specific surveys we used data from the Common Bird Census program (MMM) which has available data from 1999 (Szép et al. 2012). The Hungarian common bird monitoring scheme (MMM) is based on point count in grid cells with semi-random sampling design. The surveyed sites are $2.5 \times 2.5 \mathrm{~km}$ UTM squares (Universal Transverse Mercator geographic coordinate system), randomly selected for each observer within a minimum of $10 \mathrm{~km}$ radius area around a locality specified by the observer. Observers carried out 5 minute long point counts at 15 points, randomly selected from the 25 potential points within the $2.5 \times 2.5 \mathrm{~km}$ UTM squares, where points were separated by $500 \mathrm{~m}$. Because of the methodology used, we had several possibilities for estimation using different layers of the dataset.

(1) PAIR UTM25 - In this case the number of pairs was estimated to be 1 if at any of the observation points in the UTM square the frequency was higher than 0 .

(2) PAIR SITE2 - The number of pairs was estimated in each UTM square based on the observed frequency at the 15 observation points out of the possible 25 as 'No.pairs'='observed frequency' * 'No. of possible observation points'. We used the rounded value of 'No.pairs' as the number of pairs in the given square.

(3) PAIR $100 \mathrm{M}$-The density (pair $/ \mathrm{km}^{2}$ ) was estimated based on the number of observed individuals inside the $100 \mathrm{~m}$ radius circles around the observation points within each surveyed quadrat. The density value of the $100 \mathrm{~m}$ radius circles was used to extrapolate to the area of the UTM square $\left(6.25 \mathrm{~km}^{2}\right)$.

The national population estimates and their $95 \%$ confidence intervals were calculated based on the individual estimations for the UTM squares by the 3 different methods as:

\section{$N^{\prime}($ population size $)=n^{\prime} * K$}

where:

n': the average number of individuals in an UTM square

$\mathbf{K}$ : the possible number of UTM squares in the study area $(14,886)$

\section{$\mathrm{S}^{2}{ }_{\mathrm{N}}$ : variance of the estimated population} size:

$$
S_{N^{\prime}}^{2}=\frac{K(K-r)}{r} * S_{n^{\prime}}^{2}
$$

where:

$\mathbf{s}^{2} \mathbf{n}$ ': variance of the average number of individuals by UTM squares

r: the number of surveyed UTM squares

\section{N'95\% confidence interval}

N' 95\% minimum confidence interval: N'$1,96 * \mathrm{~S}_{\mathrm{N}}$

N' $95 \%$ maximum confidence interval: $\mathrm{N}^{\prime}+1,96 * \mathrm{~S}_{\mathrm{N}}$ 
where:

$\mathbf{S}_{\mathbf{N}}$ : standard deviance of the estimated population size

$$
S_{N^{\prime}}=\sqrt{S_{N^{\prime}}^{2}}
$$

The population estimation (minimum 95\% $\mathrm{CI}$ - maximum $95 \% \mathrm{CI}$ ) with the three different methods is respectively (1) 57516824 pairs, (2) 13,405-17,620 pairs, (3) $51,936-74,886$ pairs. The large differences between the estimations are because the method links an observation of a breeding individual to very different hypothetical home ranges ( 3.1 ha -25 ha -625 ha), so to select the best estimation we have to find the best estimate for the species' home range.

The home range of the species was studied in detail in Switzerland and Spain. Individual home ranges varied between 4.4 and 72.2 ha (mean \pm SD: $39.6 \pm 25.4$ ha, Tagmann-Ioset et al. 2012) in Switzerland and between 7.41-30.76 ha (mean \pm SD: 12.78 \pm 5.96 ha, MCP method) and between $6.52-$ 26.46 ha (mean \pm SD: $12.78 \pm 5.96$ ha, kernel method) in Spain (Barbaro et al. 2008).
Based on this information we decided to use the (2) method, which uses 25 ha area for estimation, which is fairly close to the home range of the Hoopoe. By this way the best population estimation is $13,500-17,500$ pairs, which is very close to the previous estimates of 10,000-17,000 pairs.

We estimated the population trends based on the MMM dataset, with the standardized EBCC methodology with the TRIM software package (Szép et al. 2012). The population trend between 1999-2014 showed stable trend (slope $=-1.3 \% \mathrm{SE}=2.5 \%$ ) (Figure 2). The long term population trend in Hungary between 1980-2012 is estimated to be decreasing by $30-50 \%$ based on the best available expert knowledge (BirdLife International 2015b).

\section{Migration and dispersion}

A thorough study of European ring recoveries of the Hoopoe demonstrated the existence of a migratory divide for the autumn migration period in Central Europe,

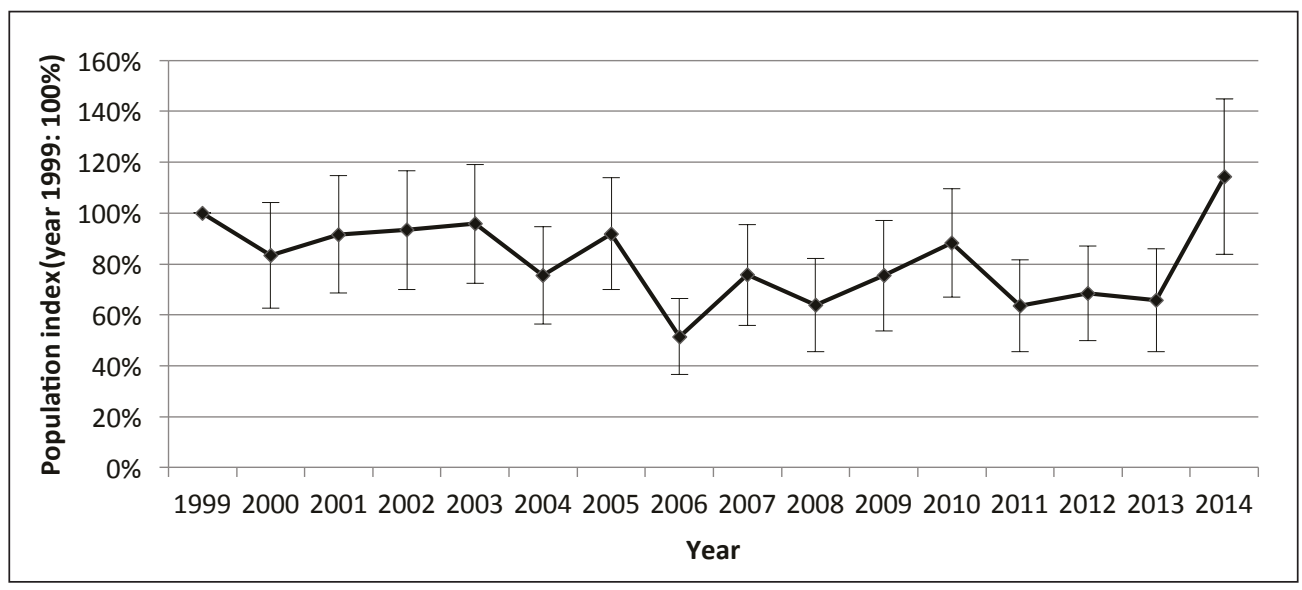

Figure 2. Annual population indices $( \pm \mathrm{SE})$ of the surveyed Hoopoe population in the frame of the MMM during 1999-2014 based on TRIM imputed index. Base year was 1999

2.ábra A búbosbanka felmérés évi populációs indexei 1999-2014 között az MMM keretében felvéve. Alapév 1999 


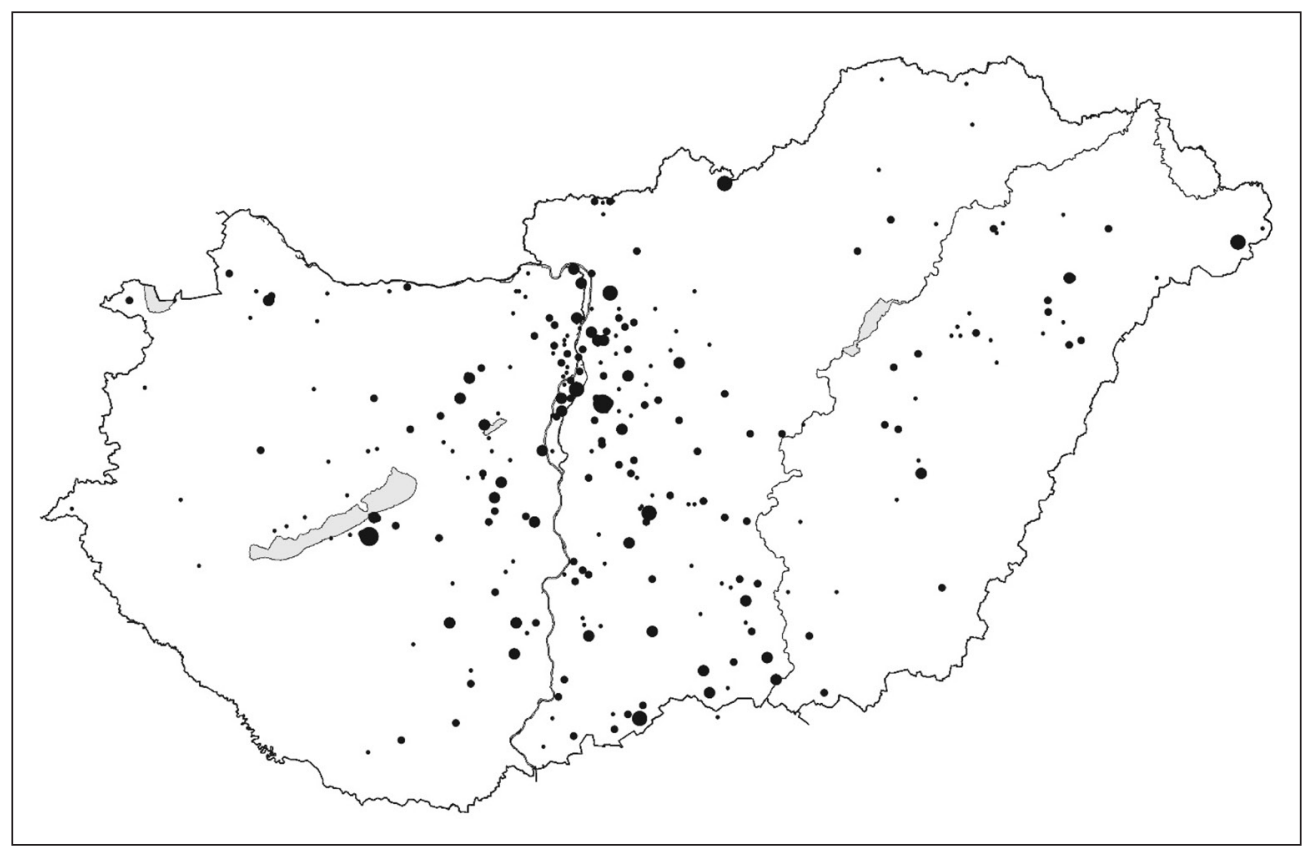

Figure 3. The distribution of Hoopoe ringing sites in Hungary. The size of the black dots is proportional to the number of ringed birds

3. ábra A búbosbanka gyűrüzési helyeinek eloszlása Magyarországon. A fekete körök mérete arányos a meggyürüzött madarak számával

at approximately $10-12^{\circ} \mathrm{E}$ longitude running through Germany, Austria, Switzerland, and Italy (Reichlin et al. 2009). There is very little knowledge about the migration routes of the Hoopoe after leaving the Mediterranean for their wintering quarters in the sub-Saharan Africa. Only one ring recovery is known in the described sub-Saharan wintering range (ringed on 19 April 1993 in Tuscany, Italy, reported dead on $1^{\text {st }}$ November 1993 in Aderbissinat, Niger, distance 2981 $\mathrm{km})$. The new technology of light-level geolocators made it possible to gain new information on the migration and sub-Saharan wintering grounds. In a study from Switzerland 19 Hoopoes were tagged with geolocators and 4 were successfully recovered (Bächler et al. 2010). The analyses showed, that 2 of these birds followed a southwestern route through Iberia stopping over in southern Spain than crossing the Strait of Gibraltar, and after crossing the Sahara spent the winter in the border area of Mauritania and western Mali. Both birds migrated back in spring on a more easterly route making a loop migration. The third bird did a similar but $1000 \mathrm{~km}$ more easterly migration spending the winter in central Algeria. The fourth bird provided only fragmented information but migrated to the southeast in the direction of Italy and Albania. The analysis of isotope content of winter-grown feathers, could only very roughly delineate the winter distribution of the Hoopoe, strengthening the result from the other studies, that Spanish and Swiss Hoopoes winter in the western part of the Sahel zone (Reichlin et al. 2013).

Breeding dispersal is common in Hoopoes, compared with other bird species. A dispersal study by Bötsch et al. (2012) 


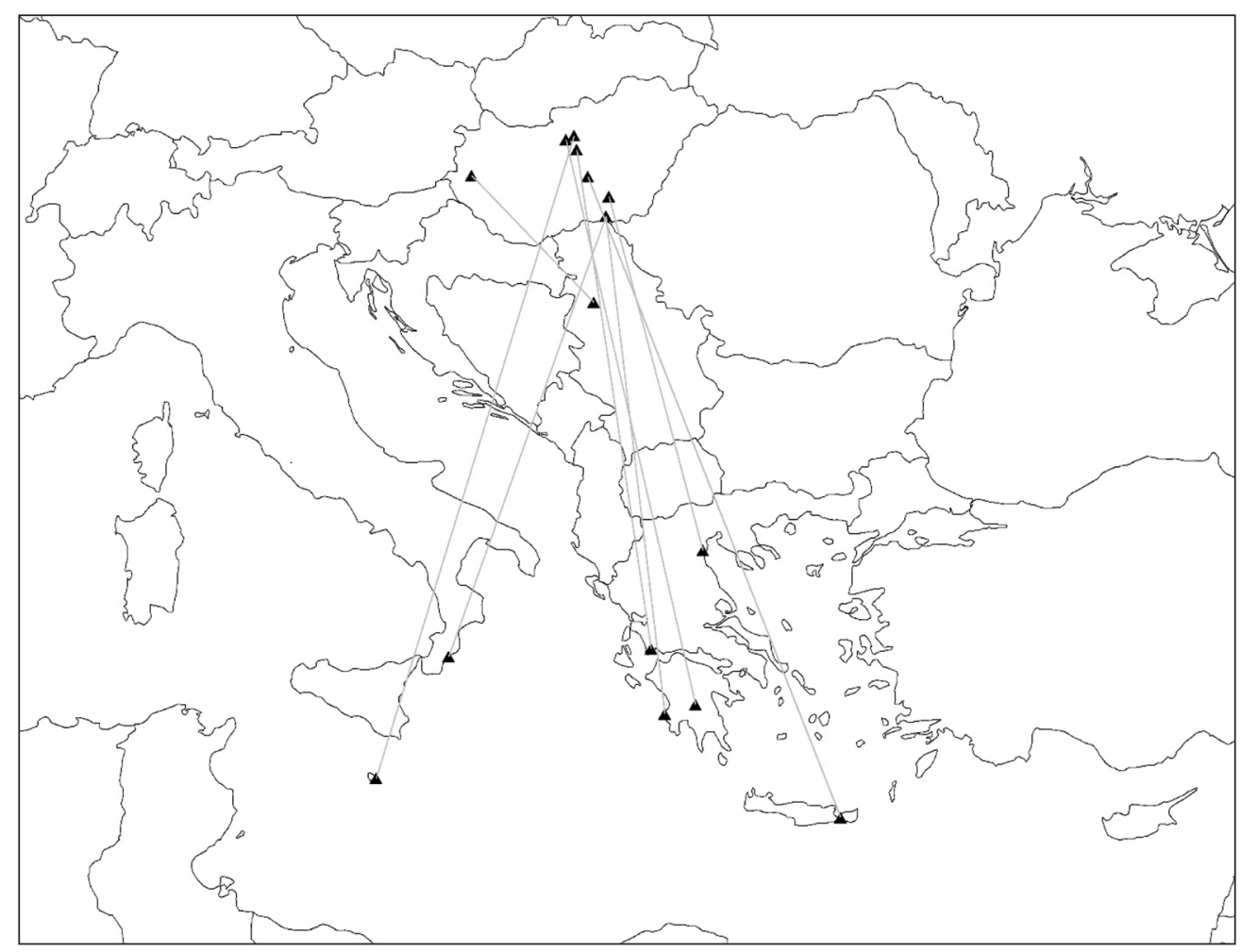

Figure 4. Foreign recoveries of Hoopoes ringed in Hungary

4. ábra Magyarországi gyűrűzésű búbosbankák visszafogása külföldön

found, that between years, females dispersed more often and over longer distances than males (mean distance, females $=1.98$ $\mathrm{km}$; males $=0.83 \mathrm{~km}$ ), but dispersal was only weakly affected by age and previous reproductive success. Dispersal within a year also differed between sexes (mean distance, females $=1.45 \mathrm{~km}$; males $=0.46 \mathrm{~km}$ ) and varied little with age or previous reproductive success. Dispersal probability within years was lower and occurred over shorter distances than dispersal between years.

The Hungarian population of the Hoopoe is migratory, departing in August for the presumed wintering ground south of the Sahara. It arrives back in April. Based on recovery data from Serbia-Montenegro, Greece, Italy and Malta, the Hungarian breeding popula- tion migrates east-southeast to south-southwest. No recovery has been reported from the wintering ground (Magyar 2009). Since the publication of the Hungarian Bird Ringing Atlas there were very little additional data gathered. There are records of 1645 Hoopoes ringed between 1908-2014 in the Hungarian Bird Ringing Databank. A large percentage of these bird $(1080,65 \%)$ were ringed as nestlings. The distribution of ringing is in good accordance with the observation data (Figure 3). We have only 31 recaptures and all are local ones between 0-13 $\mathrm{km}$ from the site of ringing. There are only 8 birds recovered abroad in Greece (5), Italy (1), Malta (1) and Serbia (1) (Figure 4). Two of these birds were hunted, but we don't know the circumstances of recovery 
for the others and all recoveries are old from 1929-1963.

Based on international studies we can presume and on the very little information we have about the species in our country, Hungarian populations migrates on a south-southeast direction in autumn, winters in the eastern parts of the Sahel, possibly in Chad and Sudan and migrates back in spring following a loop migration pattern further to the east.

\section{Conservation}

The red list assessments evaluated the species as Least Concern (LC) status on the global, European and EU27 level as well, based on the extremely large range, the large overall population and the stable population trend (BirdLife International 2015a, 2015b). In Hungary the species is protected with a nature conservation value of 50,000 Hungarian Forints.

The species is hunted in the Mediterranean region (Krištín \& Kirwan 2014). Food quality and accessibility has been shown to affect reproductive success (Martín-Vivaldi et al. 1999, Fournier \& Arlettaz 2001) as through the availability of suitable nesting

\section{References}

Bank, L. 2015. Az év madara 2015-ben: a búbosbanka [The bird of the year in 2015: The Hoopoe]. Madártávlat 22(1): 4-7. (in Hungarian)

Bankovics, A. 1984. Búbosbanka [Hoopoe]. - In: Haraszthy, L. (ed.) Magyarország fészkelő madarai [The breeding birds of Hungary]. - Natura, Budapest, p. 124. (in Hungarian)

Bächler, E., Hahn, S., Schaub, M., Arlettaz, R., Jenni, L., Fox, J. W., Afanasyev, V. \& Liechti, F. 2010. Year-round tracking of small trans-Saharan migrants using light-level geolocators. - PLoS ONE 5(3): e9566. DOI: 10.1371/journal.pone.0009566

Barbaro, L., Couzi, L., Bretagnolle, V., Nezan, J. \& Vetillard, F. 2008. Multi-scale habitat selection cavities as a result of habitat changes after agricultural intensification (Berthier et al. 2012, BirdLife International 2015b).

The present status of the Hoopoe in Hungary seems stable, however the general decline of farmland and long-distance migratory birds (Szép et al. 2012) raises concerns and makes it necessary to monitor the population level and changes as well as the possible threats more closely. The species depends on cavities as nesting places, which are particularly scarce on the lowlands of Hungary and are known to be a limiting factor for other cavity nesting species like the Roller (Coracias garrulus) (Kovács et al. 2008). This is very possibly limiting the Hoopoe population as well, so the provision of artificial nest boxes can be an important conservation measure in the future.

\section{Acknowledgements}

We are thankful to all volunteers of MME/ BirdLife Hungary and professional staff of the Hungarian National Park directorates who collected ringing and monitoring data. We are grateful to two anonymous reviewers for helpful comments on the manuscript.

and foraging ecology of the Eurasian Hoopoe (Upupa epops) in pine plantations. - Biodiversity and Conservation 17(5): 1073-1087. DOI: 10.1007/s10531-007-9241-z

Berthier, K., Leippert, F., Fumagalli, L. \& Arlettaz, R. 2012. Massive nest-box supplementation boosts fecundity, survival and even immigration without altering mating and reproductive behaviour in a rapidly recovered bird population. - PLoS ONE 7(4): e36028. DOI: 10.1371/journal.pone.0036028

BirdLife International 2004. Birds in Europe: population estimates, trends and conservation status. Cambridge, UK, Birdlife International, Birdlife Conservation Series, No. 12., p. 173. 
BirdLife International 2015a Species factsheet: Upupa epops. - Downloaded from http://www.birdlife. org on $09 / 12 / 2015$.

BirdLife International 2015b European Red List of Birds. - Luxembourg: Office for Official Publications of the European Communities

Bötsch, Y., Arlettaz, R. \& Schaub, M. 2012. Breeding dispersal of Eurasian Hoopoes (Upupa epops) within and between years in relation to reproductive success, sex, and age. - Auk 129: 283-295. DOI: 10.1525/auk.2012.11079

Fournier, J. \& Arlettaz, R. 2001. Food provision to nestlings in the Hoopoe Upupa epops: implications for the conservation of a small endangered population in the Swiss Alps. - Ibis 143(1): 2-10. DOI: 10.1111/j.1474-919X.2001.tb04163.X

Hadarics, T. \& Zalai, T. 2008. Nomenclator Avium Hungariae - An annonated list of the birds of Hungary. - MME Birdlife Hungary, Budapest, p. 199. (in Hungarian with English Summary)

Homonnay, N. 1938. A búbosbanka, Upupa epops L. fészkelési viszonyai a Balaton-mellékén [The breeding of the Hoopoe Upupa epops in the region of Balaton]. - Kócsag 9-11: 72-79.

Kovács, A., Barov, B., Orhun, C. \& Gallo-Orsi, U. 2008. International Species Action Plan for the European Roller Coracias garrulus garrulus. BirdLife International for the European Commission, pp. 52

Krištín, A. \& Kirwan, G. M. 2014. Common Hoopoe (Upupa epops). - In: del Hoyo, J., Elliott, A., Sargatal, J., Christie, D. A. \& de Juana, E. (eds.) Handbook of the Birds of the World Alive. - Lynx Edicions, Barcelona (retrieved from http:/www. hbw.com/node/55871 on 25 February 2015)

Magyar, G., Hadarics, T. \& Waliczky, Z. 1998. Nomenclator avium Hungariae: An annotated list of the birds of Hungary. - KTM Természetvédelmi Hivatal Madártani Intézete, Magyar Madártani és Természetvédelmi Egyesület, Winter Fair, pp. 202

Magyar, G. 2009. Búbosbanka [Hoopoe]. - In: Csörgö, T., Karcza, Zs., Halmos, G., Magyar, G., Gyurácz., J., Szép, T., Bankovics, A., Schmidt, A. \& Schmidt, E. (eds.) Magyar Madárvonulási Atlasz [Hungarian Bird Migration Atlas]. - Kossuth Kiadó Zrt., Budapest, pp. 382-383. (in Hungarian with English Summary)
Martín-Vivaldi, M., Palomino, J. J., Soler, M. \& Soler, J. J. 1999. Determinants of reproductive success in the Hoopoe Upupa epops, a hole-nesting non-passerine bird with asynchronous hatching. - Bird Study 46: 205-216. DOI: 10.1080/ 00063659909461132

Martín-Vivaldi, M., Martínez, J. G., Palomino, J. J. \& Soler, M. 2002. Extrapair paternity in the Hoopoe Upupa epops: an exploration of the influence of interactions between breeding pairs, non-pair males and strophe length. - Ibis 144(2): 236-247. DOI: 10.1046/j.1474-919X.2002.00044.x

Reichlin, T. S., Schaub, M., Menz, M. H., Mermod, M., Portner, P., Arlettaz, R. \& Jenni, L. 2009. Migration patterns of Hoopoe Upupa epops and Wryneck Jynx torquilla: an analysis of European ring recoveries. - Journal of Ornithology 150(2): 393-400. DOI: 10.1007/s10336-008-0361-3

Reichlin, T. S., Hobson, K. A., Van Wilgenburg, S. L., Schaub, M., Wassenaar, L. I., Martín-Vivaldi, M., Arlettaz, R. \& Jenni, L. 2013. Conservation through connectivity: can isotopic gradients in Africa reveal winter quarters of a migratory bird? Oecologia 171: 591-600. DOI: 10.1007/s00442012-2418-5

Schaub, M., Reichlin, T. S., Abadi, F., Kéry, M., Jenni, L. \& Arlettaz, R. 2012. The demographic drivers of local population dynamics in two rare migratory birds. - Oecologia 168(1): 97-108. DOI: 10.1007/s00442-011-2070-5

Snow, D. W. \& Perrins, C. M. 1998. The Birds of the Western Palearctic (Concise Edition). Vol. 1. Non-Passerines. - Oxford University Press, Oxford, UK, pp. 1830

Szép, T., Nagy, K., Nagy, Zs. \& Halmos, G. 2012. Population trends of common breeding and wintering birds in Hungary, decline of long-distance migrant and farmland birds during 1999-2012. - Ornis Hungarica 20(2): 13-63. DOI: 10.2478/ orhu-2013-0007

Tagmann-Ioset, A., Schaub, M., Reichlin, T. S., Weisshaupt, N. \& Arlettaz, R. 2012. Bare ground as a crucial habitat feature for a rare terrestrially foraging farmland bird of Central Europe. - Acta Oecologica 39: 25-32. DOI: 10.1016/j. actao.2011.11.003 